\title{
INOVASI PENDIDIKAN KEAHLIAN SEKOLAH MENENGAH KEJURUAN BERBASIS PESANTREN DI KABUPATEN BANYUWANGI
}

\author{
Kholilur Rahman \\ (IAI Ibrahimy Genteng)
}

\begin{abstract}
Abstrak:
Kertas kerja ini menganalisa inovasi pendidikan yang dijalankan Sekolah Menengah Kejuruan (SMK) berbasis pesantren di Kabupaten Banyuwangi. Dengan menggunakan cultural and micro politics of school theory sebagai kerangka baca, kekuasaan (politik) dapat menjadikan perencanaan inovasi berjalan lebih luas dibandingkan bila dilaksanakan dengan pendekatan kultural, struktural, atau rasional pimpinan lembaga. Inovasi yang behubungan dengan kualitas proses pelaksanaan pendidikan vokasi sangat ditunjang oleh atribusi guru profesional dan latar pengalaman pendidikan. Selanjutnya, dalam kaitannya dengan student outcomes dan public relation dengan dunia usaha, kepemimpinan dan interrelasi kuasa kiai serta pesantren menjadi penentu sebuah efektifnya inovasi pendidikan vokasi di bawah naungan pesantren.
\end{abstract}

Kata Kunci: Inovasi Pendidikan; Mutu Pendidikan; SMK berbasis Pesantren.

\section{Abstract:}

This paperwork analyzes innovation in education by High Vocational School (SMK) under pesantren institution in Banyuwangi Regency. Within the framework of cultural and micro poliotics of school theory, power (politics) is able to optimize innovation planning rather than it is within approaches of cultural, striuctural, or rationale of institutional leaders. Innovation in terms of quality of vocational education is highly supported by professional teachers and their experience beackground in education. Further, in terms of student outcomes and public relations with workplaces, leadership and interrelation of kiai's power and pesantren become crusial factor enhancing edeucational innovation in vocational school under pesantren.

Keywords: Innovation in Education; Quality of Education; Pesantrenbased Vocational School. 


\section{A. Pendahuluan}

Perdebatan klasik terkait konsep dunia pendidikan dan terus berkelindan hingga hari iniadalah terkait pengarusutamaan bentuk subtantif pendidikan itu sendiri. Dengan tujuan menjaga sustainsibilitas identitas serta kebudayaan Indonesia, pengetahuan/kompetensi, vokasi (life skill), atau karakter menjadi misi sekaligus dialektika yang terus mengemuka. Paradigma kognisi lebih penting dibanding dua hal lain, umumnya, digagas oleh para pemikir pendidikan dari dunia akademis murni, di mana keyakinan mereka adalah 'pengetahuan akan menghasilkan kepribadian serta pengalaman' untuk menghadapi semua persoalan kehidupan nyata yang ada di masyarakat. ${ }^{1}$ Sedangkan paradigma vokasi (atau yang juga disebut sebagai broad-based education system) meyoritas diusulkan oleh para pakar pendidikan yang lebih realistis melihat kepentingan dan pembangunan ekonomi lebih penting dibandingkan aspek pengetahuan. ${ }^{2}$ Adapun generasi ketiga, di mana karakter lebih penting, banyak disumbang oleh pemikir sosiolog pendidikan yang melihat tantangan dunia global yang mulai bergeser secara sosiologis. ${ }^{3}$ Fenomena yang demikian, senyatanya, cukup sering dilihat oleh rakyat Indonesia. Bahkan, ada logos umum di lingkungan system pendidikan nasional Indonesia, yakni; pergantian menteri (sebagai pemegang saham terbesar membangun system pendidikan) akan mendekonstruksi system yang dibangun oleh menteri sebelumnya. ${ }^{4}$ HAR Tilaar, mungkin adalah salah seorang pakar pendidikan yang sangat concern menilai perjalanan kebijakan ini; dimulai dari pembangunan dan pembentukan budaya pendidikan era kemerdekaan, hingga pasca reformasi serta pemberlakuan otonomi pendidikan di Indonesia. Tajuk-tajuk yang dihasilkan oleh HAR Tilaar memang tidak banyak berbeda dengan asumsi awal yang penulis sebutkan di awal. Pertama, orientasi pendidikan di Indonesia berkepentingan untuk menentukan arah perjuangan identitas kebangsaan. Maka dari itu, pendidikan kebudayaan Indonesia (cultural and identical dimensions) menjadi sangat penting. Pendidikan kewarganegaraan (citizenship education) dijadikan pijakan untuk mengarahkan komponen ajar lainnya. Kedua, era pembangunan dan pengembangan kenegaraan. Pada sisi ini, pendidikan vokasi pertama kali digulirkan pemerintah melalui sekolah-sekolah teknik (STM). Tujuannya adalah menyangga program pembangunan ekonomi yang direncanakan oleh Presiden Soeharto. Ketiga, fase integratif. Kepentingan social dan kebudayaan di-cover menggunakan pendekatan karakter, sedangkan pembangunan links and matches dibentuk melalui pendidikan vokasi. ${ }^{5}$ Kembali

${ }_{1}^{1}$ Isjoni, Pendidikan sebagai Investasi Masa Depan, (Jakarta: Yayasan Obor Indonesia, 2006), 23.

2 Tim Depdiknas, Rencana Strategis Pendidikan Nasional; Konferensi Nasional Revitalisasi Pendidikan Nasional (Jakarta: Depdiknas, 2006), xxi.

3 Ali Maksum, Sosiologi Pendidikan; buku perkuliahan S1 (Surabaya: UINSA Press, 2013), 26.

4 Darmaningtiyas, Pendidikan yang Memiskinkan (Jogjakarta: Galang Press, 2004), 61.

5 HAR Tilaar merupakan salah seorang pakar pendidikan yang sangat concern melihat bagaimana perjalanan dunia pendidikan di Indonesia. Salah dua dari karya monumentalnya 
pada fase fluktuasi kebijakan pendidikan - berasaskan pada nalar dan latar geneologis menteri di atas - tercatat pada masa kepemimpinan Presiden Susilo Bambang Yudhoyono (SBY) dan menteri Pendidikan dan Kebudayaan waktu itu, M. Nuh. ${ }^{6}$ Alasan pemerintah kala itu ialah karena telah selesainya konsolidasi krisis multi-dimensi yang dihadapi Indonesia, termasuk rekonsiliasi politik pasca reformasi. Selain factor tersebut, stabilitas keekonomi Indonesia memang sedang menanjak, dunia usaha pun membutuhkan banyak alumni lembaga pendidikan yang memiliki life skill dibandingkan sekedar memiliki pemahaman kompetensi akademik semata. Untuk itulah, slogan "SMK Bisa"7 akhirnya menjadi pilihan pemerintah menjawab keinginan dunia usaha tersebut. Demikian pula, pada level pendidikan tinggi, di Tahun 2012 pemerintah menerapkan kurikulum yang cenderung menyediakan aktivitas profesi. Di Perguruan Tinggi di berlakukan Kerangka Kualifikasi Nasional Indonesia (KKNI). ${ }^{8}$ Pada kesimpulan, pasca tahun 2010 concern pemerintah berpihak terhadap kepentingan penyediaan Sumber Daya Manusia (SDM) yang siap kerja dan memiliki mental entrepreneurship (kewirausahaan).

Kampanye pemerintah melalui pendidikan vokasi tersebut, akhirnya, direspon pula oleh pemerintah daerah dan masyarakat secara luas. Sebagaimana aturan Undang-Undang Pemerintahan Daerah No 23 Tahun 2014, salah satu kewenangan Pemerintah Provinsi dalam bidang pendidikan ialah mensupervisi dan menyediakan alokasi anggaran terhadap Pendidikan Menengah di daerahnya. Oleh karena kewenangan Pemerintah Daerah dan Dinas Pendidikan di daerah,

adalah Paradigma Baru Pendidikan Nasional dan Pendidikan dan Kekuasaan. Selain itu juga ada banyak yang berhubungan dengan bagaiman sisi teleologis pendidikan dari sisi kebudayaan juga harus dijaga oleh pemerintah. Dia memaparkan hal tersebut pada karya berjudul manifesto pendidikan nasional; tinjauan dari perspektif post-modernisme dan studi kultural. Pada intinya, HAR Tilaar tetap berharap agar pendidikan tidak serta merta mempertimbangkan sisi kematangan ekonomi, namun sebaliknya, juga perlu dilihat bagaimana identitas plural yang ada di Indonesia tetap bisa dijaga, serta pemerintah perlu concern terhadap bagaimana budaya-budaya negative di masyarakat bisa dikikis melalui pendidikan yang lebih memanusiakan dan memberikan kebebasan berfikir.

${ }^{6}$ Sebagaimana kita ketahui, M. Nuh sebelum menjabat sebagai menteri merupakan Guru Besar sekaligus Rektor Institut Teknologi 10 November Surabaya. Dia pun sangat dikenal sebagai sosok yang mempercayai bahwa pengetahuan teknik (life skill) lebih penting dibandingkan pengetauan akademik semata. Sebagaimana ruang pengalamannya sebagai rektor di kampus teknik.

7 Yohanes Enggar Harususilo, "Lulusan SMK jadi pengusaha? Bisa!" kompas.com, 17 September 2018 https://edukasi.kompas.com/read/2018/09/17/21413501/lulusan-smk-jadipengusaha-bisa. Diakses pada 23 September 2018.

8 Fitri, "Kurikulum Nasional berbasis Kompetensi Harus mengacu pada KKNI" Ristekdikti, http://lldikti12.ristekdikti.go.id/2013/04/28/kurikulum-nasional-berbasis-kompetensimengacu-pada-kkni.html. Diakses pada 23 Agustus 2018. 
keberadaan SMK kemudian banyak muncul di Pondok Pesantren ${ }^{9}$ - sebagai lembaga tradisional yang memiliki basis social di Jawa Timur. Data Universitas Muhammadiyah Malang mencatat ada 224 SMK Negeri dan 1.001 SMK Swasta di Jawa Timur. Di Banyuwangi sendiri ada ada 7 SMK Negeri, serta 29 SMK Swasta, 10 dan sebagaimana paparan kepala dinas Pendidikan, 70\% SMK di Banyuwangi ada di bawah naungan pesantren atau berada di bawah naungan organisasi Islam (baca; Muhammadiyah dan Nahdlatul Ulama'). ${ }^{11}$

Berdasarkan pada fakta-fakta dan pergeseran model kebijakan pendidikan dari tingkat nasional hingga regional di atas, tulisan ini sejatinya akan lebih banyak memotret bagaimana pendekatan-pendekatan inovatif yang dilaksanakan oleh SMK berbasis Pesantren untuk bersaing dengan pendidikan vokasi pada lingkungan serupa, atau dengan SMK yang didirikan oleh pemerintah atau kelompok/organisasi masyarakat tertentu. Selain itu juga, tulisan ini akan menggambarkan dari mana sumber inovasi serta implementasi inovasi yang dilaksanakan, sehingga menjadi added values yang tidak sekedar mengandalkan pada climate (iklim) lingkungan kepesantrenan atau nilai religiusitas yang hidup di pesantren. Pasalnya, kalau melihat kondisi di luar pesantren, kecenderungan kompetisi SMK lebih terbuka dibandingkan SMA/SMU. Artinya, ada programprogram unggulan yang di'market'kan sehingga menjadi pilihan rasional masyarakat/peserta didik untuk masuk pada lembaga pendidikan vokasi tersebut. Maka dari itu, komposisi inovasi yang ada SMK di lingkungan pesantren harus juga mempertimbangkan aspek-aspek lain, yang bisa jadi, memang berasal dari lingkungan pesantren. ${ }^{12}$

Untuk mengeksaminasi inovasi yang dijalankan di SMK berbasis pesantren penulis menentukan tiga lokus penelitian pada tulisan ini; pertama, SMK Bustanul Falah Genteng. Kedua, SMK Darussalam Bolokagung. Ketiga, SMK Manbaul Ulum

${ }^{9}$ Untuk melihat detail bagaiamana treatment yang dilaksanakan oleh Pemerintah Jawa Timur bisa dibaca dalam Maskuri "Kebijakan Sekolah Menengah Kejuruan di Lingkungan Pondok Pesantren; Studi terhadap Peraturan Daerah Jawa Timur No 9 Tahun 2014 tentang Penyelenggaraan Pendidikan" (Disertasi --- UIN Sunan Ampel Surabaya Tahun 2018).

10 Universitas Muhammadiyah Malang, "Data SMA dan SMK Propinsi Jawa Timur, http://www.umm.ac.id/id/pages/jawa-timur-2.html (diakses pada 23 Agustus 2018). Data UNNES menyebutkan ada 73 SMK Swasta yang ada di Kabupaten Banyuwangi... paparan jumlah SMK, Cah Pinter, Daftar Alamat SMK se-Kab. Banyuwangi, blog.unnes.ac.id, 06 Agustus 2016, http://blog.unnes.ac.id/daftardaftar/daftar-alamat-smk-se-kab-banyuwangi/. Diakses pada 23 Agustus 2018.

${ }^{11}$ www.umm.ac.id, blog.unnes.ac.id, Data SMK.

12 Berikut ini adalah beberapa nilai lebih pendidikan pesantren dan SMK berbasis pesantren yang diidentifikasi melalui beberapa pendekata. Lihat; Marzuki "Pesantren Kejuruan; suatu alternative Lembaga Pendidikan Islam" dalam Proceeding AICIS 2012 yang diselenggarakan di Surabaya. Bandingkan dengan Siti Aisyah "SMK Pesantren; Sebuah Penelusuran Akar Ideologi Pendidikan" Dirasat; Jurnal Manajemen Pendidikan Islam Vol. 3 No. 1 (Desember 2017), 81-102. 
Muncar. Pemilihan tiga SMK ini bukan karena alasan geografis semata, melainkan lebih sebab mutu pendidikan yang diakui sebagai bagian dari SMK Model di Kab. Banyuwangi. Kendati, harus juga diakui, ketiga SMK ini memiliki perbedaan pendekatan untuk mengembangkan budaya mutu di lingkungan pendidikan mereka. Untuk mengetahui bagaimana perbedaan-perdaan tersebut terjalin, penulis akan menggunakan cultural and micro politics of school theory sebagai kerangka baca dalam tulisan ini. ${ }^{13}$ Sedangkan landasan teori yang akan digunakan menggunakan teori inovasi manajemen dan manajemen inovasi di dalam budaya perusahaan. Sebagai sumber utama melakukan budaya kolaborasi pada sebuah organisasi. ${ }^{14}$ Agar lebih memudahkan membaca artikel ini, maka penulis akan membaginya menjadi tiga sub-bahasan; pertama, sumber dan pelaksanaan inovasi pendidikan. Kedua, model-model inovasi di dalam konsep broad-based education system. Ketiga, paparan dan analisis data penelitian.

\section{B. Sumber dan Pengelolaan Inovasi Pendidikan}

Dalam hal ini ada dua hal penting yang akan dibahas, pertama apa dan mengapa harus melakukan inovasi pendidikan. Kedua, model-sustaining sebuah inovasi yang dijalankan secara kelembagaan, dari sudut pandang manajemen

13Daniel L. Duke dan Robert Lynn Canady sempat membuat proyek riset ambisius yang ingin memisahkan keberadaan sekolah dari kepentingan nasional. Artinya, ia ingin menggambarkan bahwa sekolah memiliki kewenangan serta kebijakan sendiri untuk memastikan proses pengembangan lembaganya, tanpa mempertimbangkan aspek makro; seperti pasar, dunia ekonomi, dan kebutuhan sosial. Proyek ambisius ini kemudian tidak dapat berjalan dengan baik. Lihat Daniel L Duke \& Robert Lynn Canady, School Policy (New Work: McGraw, 1991), xx Stephen J. Ball, akhirnya, mengagas teori micro-politics of school; sebagai pijakan masa depan pengembangan organisasi sekolah. Dia menjelaskan bahwa teori ini berasal dari cara berfikir kelompok-kelompok penggagas teori organisasi sekolah yang kemudian menghasilkan fitur teori; otoritas, koherensi tujuan, netralitas ideologi, kesadaran bersama, motivasi, konsentrasi penuh pada pengembangan, dan seni dalam pengambilan keputusan. Menurut S. J. Ball, gagasan-gagasan manajerialisme ini akan mengalami ortodoksi implementasi di sebuah sekolah yang tidak memahami seni manajerialisme. Oleh sebab itulah dia menawarkan sebuah gagasan baru berbasis pada dinamika politik sekolah. Fitur teori ini menurutnya adalah; kekuasaan, beragamnya tujuan, pentingnya ideologi, konflik yang dimanage dengan baik, kepentingan, aktivitas politik, dan kontrol yang kuat terhadap elemen lembaga pendidikan. Lihat Stephen J. Ball, Micro Politics of School; toward a Theory of School Organization (London: Springer, 2012), 19. Penggunaan teori ini, dalam pandangan peneliti, lebih cocok untuk menilai apa yang ada di SMK berbasis pesantren. Karena, dinamika konflik yang terjadi merupakan produk aktivitas politik-kekuasaan yakni antara otoritas delegatif Dinas Pendidikan Banyuwangi dan power melekat bagi pesantren yang merasa memiliki kuasa penuh untuk mengembangkan lembaga pendidikan mereka. Disamping itu, cara/strategi/pola komunikasi yang digunakan di lembaga ini cenderung politis, dibandingkan birokratis. Dengan demikian, kerangka teori peneliti yakini bisa memotret bagaimana pengelolaan inovasi ini dilakukan, sehingga dapat menciptakan budaya mutu di SMK berbasis pesantren.

${ }^{14}$ Mie Harder, et. al., Management Inovation Capabilities: A Typology and Propositions for Management Innovation Research, (Denmark: Frederiksberg, 2000), 27. 
inovasi. Dari sisi terminologis, Kata inovasi lebih pada produk individu dalam konteks berfikir kreatif, beriorentasi pada perubahan, dan hal-hal yang baru atau terbarukan, walaupun kemudian, inovasi dimaknai lebih luas dari sebelumnya. Misalnya, inovasi structural sebagai bentuk inovasi yang dihasilkan oleh kolektifitas berfikir orang-orang kreatif pada sttruktur yang sama. ${ }^{15}$ Sedangkan kata pendidikan merupakan proses transfer ilmu pengetahuan dari seseorang yang memiliki kapabilitas di bidang tersebut, kepada para murid/peserta didik yang membutuhkan ilmu tersebut. Dan pendefinisian ini hadir berdasarkan pada postulat objektif institusional atau interaksi inidividu dengan individu yang lain. ${ }^{16}$ Inovasi dimaknai sebagai proses berfikir kreatif dan mengerjakan sesuatu hal yang baru (creativity is taking up new thing and innovation is doing new thing). ${ }^{17}$

Terkait dengan bagaimana inovasi semestinya dijalanlakan Uhar Suharputra bisa dijadikan landasan untuk mengartikan manajemen inovasi pendidikan sebagai satu disiplin. Kendati dia memberikan penekanannya pada proses manajerial. Uhar Suharsaputra membangun postulasi bukunya dengan memberikan pandangan-pandangan baru bagaimana kemempinan bisa menjalankan inovasi pendidikan sebagai aspek long term process, sustainable treatment, dan memiliki challenges yang berubah-ubah. Dia juga menyatakan bahwa dalam proses penentuan suatu tindakan dinyatakan memiliki inovasi apabila melalui proses pemikiran kreatif individual, lalu disampaikan melalui pembentukan structural. Misalnya juga dia menyatakan bahwa ada proses dan jenis keputusan inovasi; dimulai dari pengetahuan, persuasi, keputusan, dan konfirmasi. Jadi, proses keputusan inovasi tidak sekedar proses adopsi terhadap fenomena yang ada di luar atau gagasan kreatif dari seorang individu, melainkan juga melibatkan stimulus dan respon dari semua elemen struktural yang ada. Kelemahannya mungkin, kajian ini memisahkan antara proses terjadinya inovasi di lingkup organisasi dengan inovasi pendidikan itu sendiri. ${ }^{18}$

Kalau di atas berkaitan dengan apa dan kenapa inovasi penting di dalam ruang lingkup pendidikan, pada sub-bahasan ini penulis akan mengelaborasi berbagai bentuk inovasi yang diimplementasi oleh lembaga pendidikan. Pada paradigma pertama ialah berhubungan dengan inovasi di lingkup institusonal; mulai dari rekayasa teknologis, hingga pada proses adaptasi lembaga pendidikan terhadap kondisi dan situasi sosial yang dihadapi. Kedua, berhubungan dengan aspek-aspek element subtantif di lingkungan pendidikan. Elemen subtantif yang penulis maksudkan meliputi; kurikulum pendidikan, guru, tenaga pendidikan, sistem pembelajaran di dalam kelas, hingga perubahan iklim/budaya organisasi lembaga pendidikan. Berdasarkan pada pembahasan tersebut, kemudian, penulis

\footnotetext{
15Uhar Suharsa Puterea, Kepemimpinan Inovasi Pendidikan; Membangun Spirit Entrepreneurship Menuju Learning School (Bandung: Refika Aditama, 2016), 300.

16 Ramayulis, Pengantar Ilmu Pendidikan Islam (Bandung: Refika Aditama, 2000), 4.

17 Hadi Sutarmanto, Kewirausahaan dan Inovasi (Jogjakarta: Fakultas Psikologi UGM, 2004), 5.

18 Puterea, Kepemimpinan Inovasi Pendidikan, 306.
} 
akan mengulasnya kembali bagaimana peran paradigma manajemen inovasi mampu men-sustain inovasi-inovasi yang telah dirumuskan secara teoritik ini.

Pada aspek inovasi kelembagaan, bagi penulis, ada dua terminology yang bisa menggambarkan bentuk-bentuk inovasi tersebut, yakni; perubahan dari sisi orientasi visi, misi, dan tujuan akhir lembaga pendidikan, lalu aspek pengelolaan (manajemen pendidikan) dari aspek kepemimpinan dan tenaga kependidikan. Irianto, dalam Syafaruddin, mengatakan bahwa ada beberapa bentuk inovasi orientasi pendidikan pasca reformasi dan desentralisasi dilaksanakan di Indonesia; 1) Aspek peningkatan mutu kelembagaan. 2) Aspek pemerataan akses pendidikan yang berkualitas. 3) Aspek efesiensi manajemen 4) Aspek peran serta masyarakat 5) Aspek Akuntabilitas. ${ }^{19}$ Syarafuddin kemudian membetikan contoh bagaimana kebijakan pemerintah terkait dengan standar mutu lembaga pendidikan melalui pembentukan Badan Standarisasi Nasional Pendidikan (BSNP). ${ }^{20}$ Dari aspek efektifitas dan efesiensi donasi terhadap dunia pendidikan, dia mengatakan bahwa hari ini pembiayaan pendidikan yang dilakukan pemerintah telah dipecah antara pemerintah pusat dan daerah ${ }^{21}$. Dan adapula kompetisi antara sekolah unggulan/efektif yang terjadi pada level kebijakan meso (baca; lingkup sekolah), yang merupakan bagian dari proses dialektis lembaga pendidikan dengan keterlibatan masyarakat secara langsung, misalnya; Sekolah berbasis IT, Sekolah berbasis ramah lingkungan hidup (adiwiyata), Sekolah umum berbasis nilai-nilai keagamaan, Sekolah Menengah Kejuruan, dan Sekolah berbasis wirausahan (entrepreneurship).

Secara sosiologis, kehadiran Sekolah berbasis Informasi dan Teknologi merupakan respon lembaga pendidikan terhadap pergeseran yang terjadi di masyarakat modern. Kondisi tersebut kemudian, memaksa lembaga pendidikan untuk merombang sistem informasi yang tradisional, pembelajaran yang klasikal, hingga desain kurikulum yang dibungkus secara tertutup dari kebutuhan masyarakat modern, menjadi lebih bisa diterima dan dikelola sesuai dengan produk-produk ilmu pengetahuan (baca; teknologi) kekinian, seperti komputerisasi data dan elemen lainnya. Tidak jauh berbeda dengan kehadiran lembaga pendidikan ramah lingkungan. Lembaga ini adalah wujud inovasi

\footnotetext{
19 Puterea, Kepemimpinan Inovasi Pendidikan, 307.

${ }^{20}$ HAR Tilaar, Standardisasi Pendidikan Nasional (Bandung: Rinneka Tjipta, 2008), 45.

${ }^{21}$ Lihat Undang-Undang Otonomi Daerah memberikan wewenang kepada Pemerinth Daerah agar membantu peningkatan mutu pendidikan melalui bantuan pendidikan daerah. Namun, pemerintah memberikan kewenangan pemerintah Desa hanya boleh memberikan bantuan kepada lembaga pendidikan anak Usia Dini, Pemerintah Kabupaten untuk Sekolah Dasar, Pemerintahan Provinsi untuk Sekolah Menengah Pertama, dan Sekolah Menengah Atas dan Perguruan Tinggi merupakan tanggung Jawab Pemerintah Pusat. Walaupun, secara factual, pembedaan kewenangan ini masih belum bisa berjalan dengan seksama. Sebab, secara politis, lembaga pendidikan masih menjadi alat kampanye efektif untuk melanggengkan kekuasaan yang telah didapatkan. (Lihat; Firman Ghana Saetapi, Rumusan Sinergi Pemerintah Daerah dan Pusat, Slideshare Kementerian Dalam Negeri).
} 
pengelola lembaga pendidikan merespon perubahan perilaku masyarakat yang mulai kehilangan awareness-nya terhadap lingkungan hidup dan penghijauan di lingkungan mereka. Jadi, lembaga pendidikan mendialekkan kebutuhan utama masyarakat dengan sistem pembelajaran yang dapat mengkonstruk masyarakat lebih concern terhadap lingkungan hidup. Bahkan, akhir-akhir ini, logos education based on social environment (pendidikan berbasis lingkungan sosial) mulai dikenalkan kepada masyarakat. Model pendidikan melihat lingkungan dari aspek yang luas, termasuk kenakalan remaja, model hidup, hedones di dalam masyarakat urban, dan instabilitas mental yang dimiliki masyarakat modern. ${ }^{22}$

Pengeloaan inovasi, sebagaimana diungkapkan oleh para penggagasnya, merupakan dari tampilnya beragam model manajemen perusahaan, yang diimplementasikan untuk menghadirkan produk yang inovatif dan compatible dengan tuntutan atau kebutuhan yang ada di dalam organisasi. Bagi J. Birkinshaw, Michael J. Mol, dan Gerry Hammel, dipaparkan sebagaimana ungkapan berikut:

"We define management innovation as the invention and implementation of a management practice, process, structure, or technique that is new to the state of the art and is intended to further organizational goals. Adopting an intraorganizational evolutionary perspective, we examine the roles of key change agents inside and outside the organization in driving and shaping four processesmotivation, invention, implementation, and theorization and labeling-that collectively define a model of how management innovation comes about..."23

Kutipan ini bermakna bahwa, manajemen inovasi adalah sebuah perluasan dan proses implementasi dari sebuah praktek manajemen, proses, struktur, dan teknik yang baru sebagai sebuah upaya sadar untuk melakukan perubahanperubahan yang ada di dalam sebuah organisasi atau menyesuaikan dengan tujuan yang diinginkan. Menurut tiga orang tersebut, maka sebuah evolusi manajerial membutuhkan apa yang disebutnya sebagai agency, struktur, dan implementasi yang hadir secara bersamaan pada sebuah organisasi.

Gary Hamel menyatakan maksud manajemen inovasi adalah pergeseran cara berfikir manajerial yang tradisional ke paradigma yang baru. Cara berfikir tradisional yang dimaksud ialah: menentukan keinginan dan merencanakan program, memotivasi dan mengarahkan usaha, mengkoordinasi dan mengontrol aktivitas, mengakumulasi dan mengalokasikan sumber daya, menggali dan mengaplikasikan pengetahuan, membangun hubungan dengan baik, mengidentifikasi dan mengembangkan talenta, memahami dan menyeimbangkan keinginan para anggota; ${ }^{24}$ dirubah menjadi cara berfikir sebagaimana berikut:

22 Dede Rosyada, Paradigma Pendidikan Demokratis (Jakarta: Prenada Media, 2004), 7-8.

23 Julian Birkinshaw, et. al., Management Innovation (London; Springer, 2004), 12. Bandingkan dengan Andy Hockley, "Managing Innovation in Educational Orgnanizations" dalam Proceedings of the International Conference Creativity and Innovation to Promote Multilingualism and Intercultural Dialogue," (Editura ARS LONGA, 2009), 177.

${ }^{24}$ Gary Hamel, "The Why, What, and How of Management Innovation" dalam Harvard Business Review, (2006), 1. 
menjadikan inovasi sebagai topik utama, pengalokasian pembiaan agar menghadirkan program program inovasi yang ada di perusahaan, meminta dan 'memaksakan' semua program serta produk yang akan dikembangkan, melatih lebih dari 600 karyawan agar menjadi inovator yang bisa merubah sistem budaya yang ada di dalam organisasi, memberikan pelatihan untuk mengembangkan inovasi-inovasi yang telah dikerjakan, mengkoordinasikan setiap unit yang ada agar berkolaborasi, berkompetisi, dan berelaborasi dalam menciptkan programprogram inovatif, membangun sistem standarisasi inovasi yang dianggap bisa mempengaruhi dan menciptakan perubahan secara global. ${ }^{25}$

Dari fakta di atas, Gary Hamel memberikan penjelasan bagaimana generalisasi konsep manajemen inovasi secara praktis. Pertama, seorang pemimpin (innovator management) harus concern terhadap problem besar yang dihadapi di organisasi tersebut. Kedua, mencari principles (nilai dasar organisasi) yang baru, termasuk merombak karyawan yang cenderung berfikir tradisional dengan pengurus yang dianggap memiliki ide-ide kreatif, sekaligus bisa mengerjakannya sesuai keinginan yang diharapkan. Ketiga, merombak model manajamen tradisional yang dianggap tidak bisa memberikan perkembangan baik bagi organisasi. Keempat, mengeksploitasi (menghancurkan/ mendistribusikan) power/kuasa yang dimiliki seorang pemimpin kepada para bawahan. Bagi Hamel, tidak ada inovasi dan kreativitas yang bisa hadir, apabila political power disematkan kepada satu orang saja. Kolaborasi dan mutual-relationship harus digunakan untuk menjamin bahwa para bawahan bisa menyampaikan gagasan yang terbesit di dalam pikirannya. ${ }^{26}$

Dalam kajian selanjutnya, Mie Harder, berdasarkan beberapa perbandingan penelitian yang ada sebelumnya, konsep manajemen inovasi yang ditawarkan J. Birkinshaw et al, tidak sepenuhnya bisa diterima secara empiric. Meskipun dia bersepakat juga, bahwa ada pakar manajemen yang beranggapan serupa dengan dia melalui istilah yang berbeda. Maka dari itu dia menawarkan beberapa konsep baru, menggunakan pendekatan kuantitatif dalam menilai relasi perilaku innovative dengan perubahan manajemen yang ada di sebuah perusahaan.

Mie Harder kemudian menjelaskan bahwa manajemen inovasi merupakan sebuah feedback dari proses managerial cognation (pemahaman terhadap aspek manajerial), yang bermakna understanding individuals' learning, decision making, perception and search behavior (pemahaman individu terhadap dirinya, proses penentuan keputusan, persepsi yang terbentuk, hingga pada pencarian model perilaku). Dengan merujuk pada pandangan psikologis, Mie menyatakan bahwa ada dua perilaku mental yang melekat pada setiap individu, yaitu: memproses secara otomatis informasi yang didapatkan, lalu melakukan eksekusi terhadap

25 Gary Hamel, "The Why, What, and How of Management Innovation", 3-6.

${ }^{26}$ Gary Hamel, "The Why, What, and How of Management Innovation", 3-6. 
gagasan dengan penuh tanggung jawab. Selain managerial cognation, ada organizational resources sebagai bagian reflektif bagaimana manajemen inovasi dijalankan di lingkungan organisasi. ${ }^{27}$ Pada intinya, dua aspek (capability and implementation diagnostic) tersebut menjadi fondasi awal bagaimana semestinya manajemen inovasi dilaksanakan di sebuah lembaga, organisasi, atau bahkan perusahaan.

Pada kesimpulannya, pembahasan di atas, memberikan gambaran bahwa pengeloaan inovasi adalah harus didahului melalui pardigma keilmiahanserta harus dilengkapi pula melalui pendekatan-pendekatan yang lebih micro-studies, dinamika dan kelenturan sikap yang lebih plural, hingga aspek-aspek perbedaan kebudayaan yang hadir sebagai nilai sebuah organisasi tersebut. Melalui eksaminasi akademik seperti itu, maka manajemen inovasi bisa digeneralisasi sebagai bentuk manajemen baru yang diimplementasikan untuk mengembangan serta meningkatkan kinerja, produktifitas, iklim organisasi, dan memberikan pengaruh pada organisasi lain yang tidak melaksanakan konsep tersebut (linking and inter-organizational studies). Hal ini serupa dengan pembahasan-pembahasan produk ilmiah manajemen lainnya seperti Total Quality Management, Management by Objective, dan Scored-Card based Management. Pengembangan postulasi inilah yang semestinya juga dibingkaikan pada model-model manajemen di luar perusahaan dan organisasi bisnis/ekonomi. Namun tampaknya, hal ini masih belum juga dilaksanakan.

\section{Pengembangan Mutu Pendidikan melalui Inovasi Pendidikan Vokasi}

Jika di atas adalah pembahasan terkait bagaimana inovasi (produk berfikir kreatif) bisa diimplementasikan serta di-sustain sebagai bentuk kekhasan dari proses kelembagaan, maka pada bagian ini, penulis akan menggambarkan dua hal penting; pertama, apa saja upaya pengembangan mutu pendidikan vokasi yang ada di Indonesia. Pada topik ini, penulis tidak mengambil pemakanaan mutu secara instrumentatif, melainkan secara subtantif. Artinya, mutu adalah sebuah nilai kesesuaian antara program yang disusun dengan hasil yang diharapkan. ${ }^{28} \mathrm{Kedua}$, penulis ingin menggambarkan bagaimana model-model pendidikan vokasi dikembangkan dikala persaingan, kolaborasi, dan ekpektasi masyarakat sangat tinggi terhadap pendidikan vokasi di Indonesia. Inovasi-

\footnotetext{
27 Mie Harder, et, al, Management Inovation Capabilities, 30

${ }^{28}$ Pemaknaan subtantif terkait mutu bisa dilihat dalam Edward Sallis, Total Quality Management in Education, (London: Kogan Page Limited, 2002), 51-52. M.N. Nasution, Manajemen Mutu Terpadu (Total Quality Management), (Jakarta: Ghalia Indonesia, 2001), 15. Sudarwan Danim, Visi Baru Manajemen Sekolah: dari Unit Birokasi ke Lembaga Akademik (Jakarta: Bumi Aksara, 2008), 53. Charles Hoy, et.al., Improving Quality in Education (London: Longman Publishing Company, 2000), 15. Sedangkan terkait instrumentasi mutu yang sering dijalankan di Indonesia bisa dilihat pada Nanang Fatah, Sistem Penjaminan Mutu Pendidikan: dalam Konteks Penerpan MBS (Bandung: Remaja Rosdakarya, 2012), 2. Dzaujak Ahmad, Penunjuk Peningkatan Mutu Pendidikan di Sekolah Dasar, (Jakarta: Depdikbud, 1996), 8.
} 
inovasi ini, penulis landaskan pada beberapa tulisan Jurnal yang memang concern terhadap perkembangan pendidikan vokasi di Indonesia; baik tingkat sekolah menengah ataupun pada pendidikan tinggi.

Sebagaimana kita ketahui, ekpektasi besar keberadaan SMK atau pendidikan Vokasi adalah penyeimbangan antara kebutuhan pasar kerja dan sumber daya yang dimiliki oleh Indonesia.Menurut Hadiwaratama dalam penyelenggaraan pendidikan kejuruan hendaknya mengikuti proses: pengalihan ilmu (transfer of knowledge) ataupun penimbaan ilmu (acquisition of knowledge) melalui pembelajaran teori; pencernaan ilmu (digestion of knowledge) melalui tugas-tugas, pekerjaan rumah, dan tutorial; pembuktian ilmu (validation of knowledge) melalui percobaan-percobaan di laboratorium secara empiris atau visual (simulasi atau virtual reality); pengembangan keterampilan (skills development) melalui pekerjaan-pekerjaan nyata di bengkel praktik sekolah, di magang di industri. Dari ke empat tahapan proses tersebut keterampilan merupakan yang paling esensial keberadaannya dalam pendidikan kejuruan. ${ }^{29}$ Bambang Sugistiyadi memberikan tawaran bagaimana perangkat program visioner dan target pengembangan mutu pendidikan vokasi bisa dicapai di Indonesia, sebagaimana table berikut:

Tabel 1. Visi Misi, dan Program yang harus dicapai dalam Pendidikan Vokasi

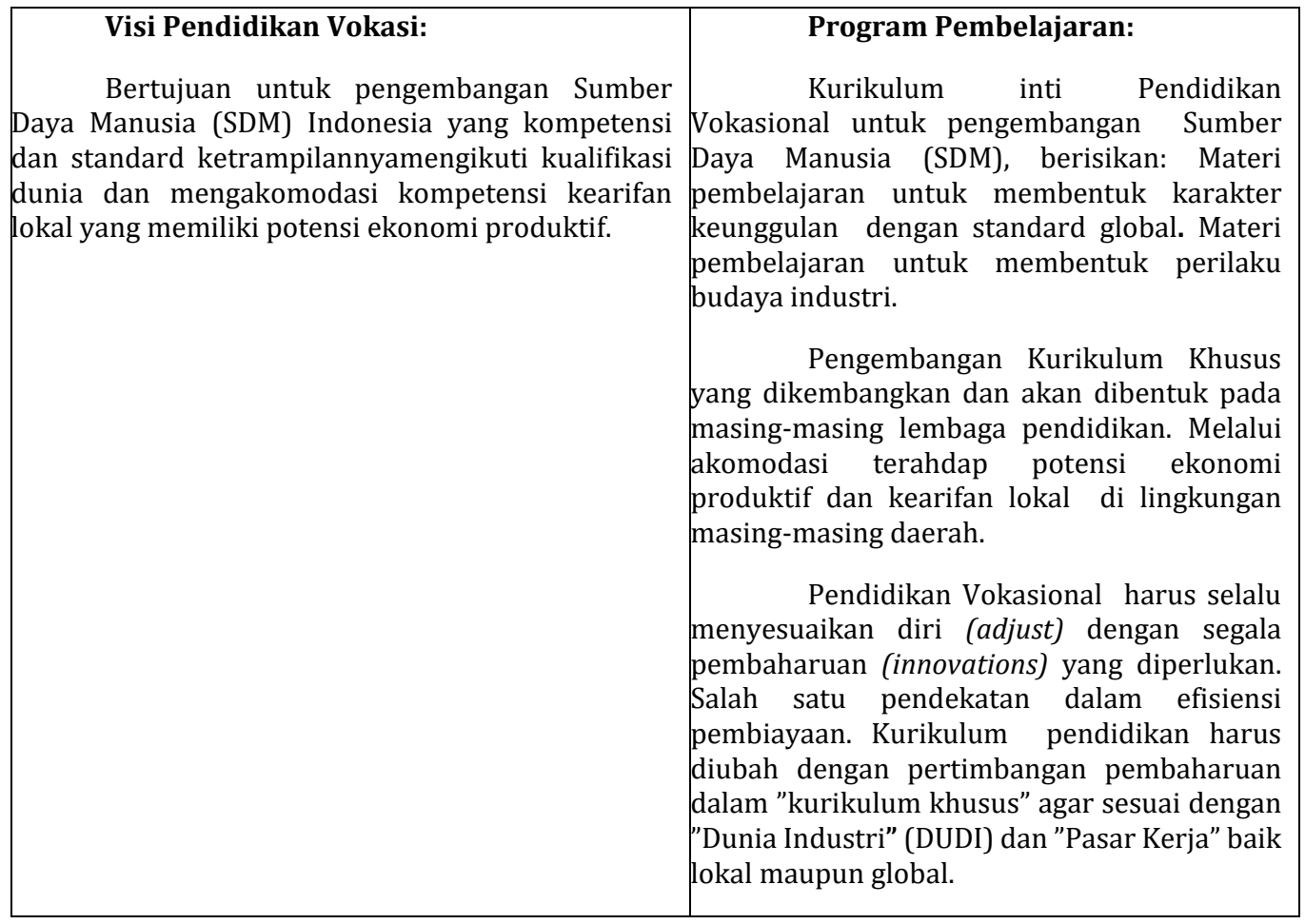

${ }^{29}$ Bambang Sugestiyadi, Pendidikan Vokasional sebagai Investasi; Strategic Option for managing Knowledge and Innovation, (Jogjakarta; UNY Press, 2011), 10. 


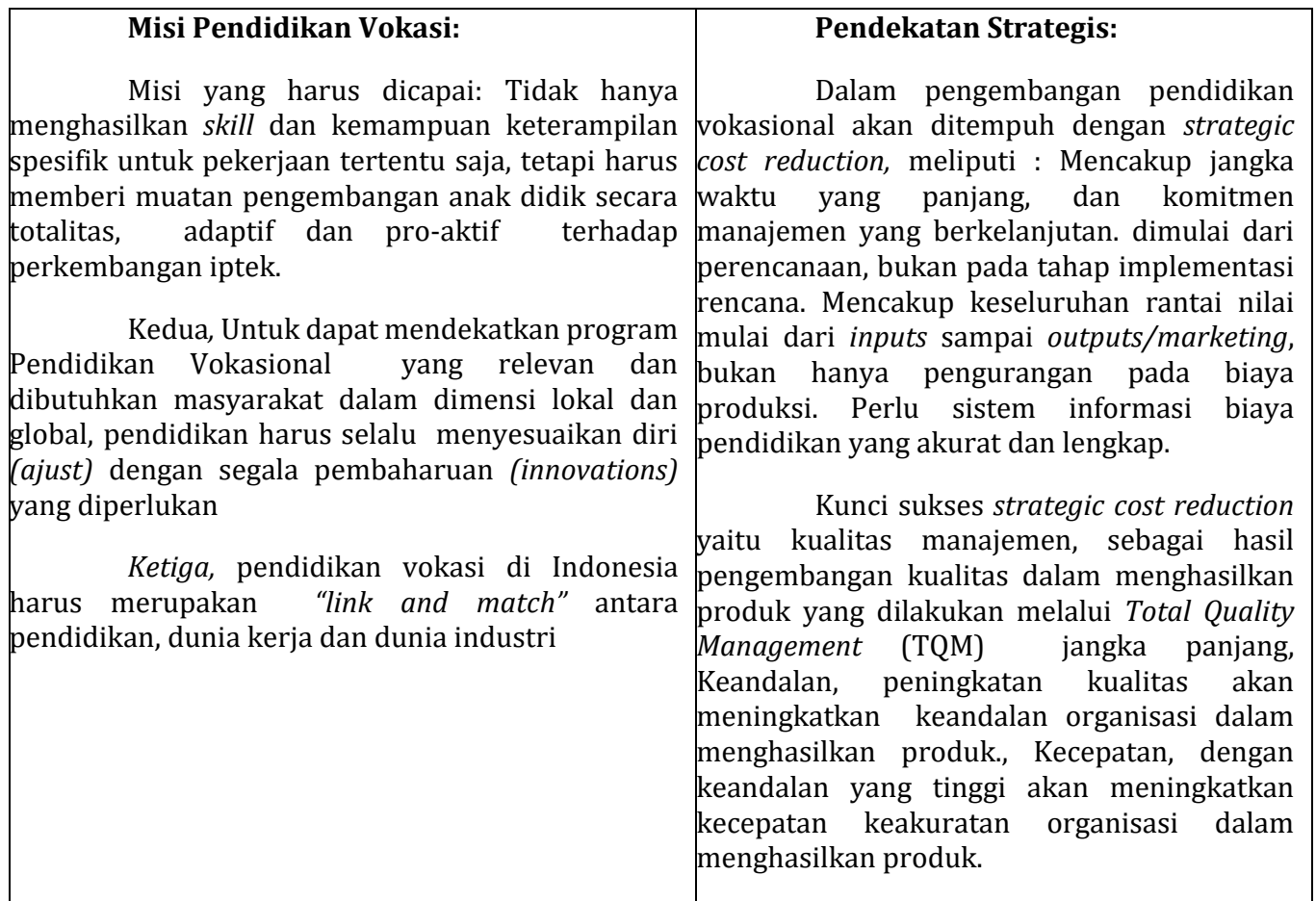

Berdasarkan tabel di atas, dapat kita ketahui bahwa pendidikan vokasi harus mendekatkan pendidikan yang diselengarakan dengan realitas sosial di masyarakat. Pada saat yang sama, pendidikan vokasi memiliki concernterhadap penyesuaian kurikulum pendidikan dengan dunia kerja. Sehingga upaya pengembangan Sumber Daya Manusia (SDM) dapat dilakukan secara optimal.

Lebih lanjut, David Newhouse \& Daniel Suryadarma, dalam Siti Qomala Khayati, menyatakan bahwa mengevaluasi output SMK relatif terhadap output sekolah menengah umum harus dengan kombinasi empat dimensi: pendapatan, pastisipasi pasar tenaga kerja, risiko pengangguran, dan kualitas pekerjaan. Mereka juga menggunakan set variabel kontrol: daerah asal seseorang lulus SMP, hasil tes, kemampuan ekonomi orang tua, dan tingkat pendidikan orang tua. Siswa yang memiliki nilai tes tinggi yang paling berpeluang masuk sekolah umum. Demikian juga, anak dari orang tua yang perpendidikan tinggi cenderung memilih sekolah umum, bukan sekolah kejuruan. SMK swasta adalah pilihan terakhir, dan melayani siswa dengan nilai tes terendah dan kurang berpendidikannya orang 
tua. $^{30}$ Laporan dari kementerian Kebudayaan hingga tahun 2016 dinyatakan bahwa:

"Dalam kurun waktu 15 tahun terakhir sampai tahun 2015, dinamika keberkerjaan lulusan SMK dan SMA menunjukkan perubahan-perubahan. Pada kurun waktu tahun 2000 - 2005, tingkat keberkerjaan lulusan SMK lebih tinggi daripada lulusan SMA. Keadaan ini berbalik pada kurun waktu 2010 - 2015, yakni tingkat keberkerjaan lulusan SMA lebih tinggi daripada lulusan SMK. Pergeseran ini ditengarai akibat dari: pertama, adanya perubahan karakteristik dunia kerja, terutama jenis-jenis pekerjaan baru yang bermunculan lebih memerlukan kapabilitas seseorang yang ditandai kemampuan general. Kedua, adanya lonjakan lulusan SMK masuk ke pasar kerja, terutama akibat dari kebijakan perluasan kesempatan memperoleh pendidikan di SMK melalui program pembalikan dari 70\% SMA ke 70\% SMK... Dilihat dari proporsi jumlah pengangguran lulusan SMK terhadap total pengangguran di negeri ini (dalam kurun waktu 1996 - 2016), persentase pengangguran lulusan SMK merangkak naik dalam kurun waktu tiga tahun terakhir, yakni dari 11,9\% pada tahun 2014 naik menjadi 19,2\% (BPS, Sakernas 1996 - 2016). ${ }^{31}$

Berdasarkan pada data-data di atas, maka sejatinya, pendidikan vokasidan inovasi merupakan sebuah entitas yang dualistic. Para pengelola pendidikan vokasi tidak bisa hanya berorientasi pada aspek internal saja, mereka juga harus berfikir bagaimana pasar kerja yang bergeser secara global ataupun regional. Maka dari itu, sedikitnya, ada empat aspek yang secara global dan nasional diusulkan sebagai model inovasi pendidikan vokasi ke depan. Empat aspek tersebut adalah:

\section{Mengedepankan Entreprenuership Values and Character}

Nuryadin Eko Rahardjo, dkk ${ }^{32}$ dan Asmar Yulasti, dkk ${ }^{33}$ adalah beberapa peneliti yang mengusulkan agar pendidikan vokasi di Indonesia mengambil arah untuk mengembangkan program kewirausahaan. Setidaknya, menurut mereka, kreatifitas, model komunikasi, kooperasi, hingga pada sikap-sikap lain yang terkandung dalam nilai/karakter seorang wirausahawan bisa melekat pada diri siswa. Hal ini juga ditambah dengan modal-modal keekonomian yang dimiliki oleh pemerintah hari ini, melalui program ekonomi kreatif atau akses bantuan keuangan yang telah lebih mudah dibandingkan sebelumnya. Selain persoalan

${ }^{30}$ Siti Qomala Khayati, “Manajemen dan Pengembangan Kurikulum Vokasi di Indonesia," Jurnal Mozaik; Islamic Education Journal Vol 1 No 2 (2016), 23.

31 Tim Kemdikbud. Revitalisasi Pendidikan Vokasi. (Jakarta: Kementerian Pendidikan dan Kebudayaan, 2016), 3.

32 Nuryadin Eko Raharjo, Sukardi, dan Husaeni Usman, "Entrepreneurial Character Education Through The School Culture in The Vocational High Schools," Jurnal Pendidikan Vokasi, Vol 8 No 2, (2018) (diterbitkan Asosiasi Dosen dan Guru Vokasi bersama Universitas Negeri Jogjakarta), 204-215.

33 Asmar Yulastri, Hendra Hidayat, dan Ganefri, "Learning Outcomes with the Application of Product Based Entrepreneurship Module in Vocational Higher Education" Jurnal Pendidikan Vokasi, Vol 8 No 2, (2018) (Asosiasi Dosen \& Guru Vokasi Indonesia), 120-130. 
pada program pembelajaran atau kurikulum yang mesti didesain berdasarkan modul kewirausahaan, adapula usulan agar iklim kewirausahaan dikoneksikan dengan sikap keseharian para siswa di lingkungan sekolah. Jadi, mereka tidak sekedar mendapatkan pembelajaran, melainkan lebih paham apa makna dibalik nilai-nilai kewirausahaan tersebut dalam bentuk kongkrit.

\section{Perluasan (advancing)TVET (Technical Vocational Education and Training)}

Pun demikian dengan program inkubasi keterampilan dan praktek kerja para siswa di lembaga pendidikan vokasi. Ada usulan dari ahli TVETyang mereka sebut sengan model pendekatan kapabilitas, sebagai alternatif sistem TVET. Wheelahan \& Moodie, Staron, Jasinski, \& Wheatherley dan Allais adalah sebagian peneliti dan pengembang TVET yang mewacanakan pendekatan kapabilitas.Bagi Wheelahan \& Moodie, ada banyak kemungkinan arah baru dalam pendekatan kapabilitas ini, mengenai hakikat kecakapan dan kerangka kebijakan untuk pengembangannya. ${ }^{34}$ Staron, Jasinski,\& Wheatherley mengaitkan pendekatan kapabilitas ini, dengan pendekatan pembelajaran, yang memperluas sistem training dengan pendekatan life-based learning.Adapun Allais mengajukan pendekatan kapabilitas sebagai alternatif pendekatan kompetensi yang dinilainya gagal dalam perluasan TVET di Afrika Selatan. ${ }^{35}$. Standing ini, menjelaskan bahwa okupasi secara umum didefinisikan oleh struktur karier. Training untuk job hanya terbatas untuk memenuhi persyaratan job, sedangkan pendidikan atau pelatihan untuk okupasi didasarkan pada prinsip pengembangan dan kemajuan, sehingga proses pendidikan dan kemajuan okupasional dikaitkan. Kapabilitas berhubungan dengan kondisi individu untuk siap terjun dalam pekerjaan dan untuk kemajuan karier dengan persyaratan okupasi yang luas. ${ }^{36}$ Okupasi yang diperluas ini untuk memberikan jawaban terhadap perubahan-perubahan praktek ekonomi dunia usaha yang ada hari ini. ${ }^{37}$

\footnotetext{
${ }^{34}$ Wheelahan \& Moodie mengidentifikasi kapabilitas bukan sekedar bentuk kemampuan umum (generic skills atau employability skills). Kapabilitas adalah atribut yang tidak dapat dipisahkan dengan okupasi (area pekerjaan) di mana seseorang disiapkan untuk memasuki okupasi itu. Argumen kuncinya adalah TVET harus menyiapkan siswa untuk suatu okupasi yang luas dalam jalur kejuruan yang didefinisikan secara longgar daripada tugas-tugas atau peran yang berkaitan dengan job khusus. Lihat L. Wheelahan and G. Moodie, Rethinking Skills in Vocational Education and Training: From Competencies to Capabilities, (NSW: Australian Education Union, 2011), 34.

35 D. Chen, Vocational Schooling, Labor Market Outcomes, and College Entry; Policy Research Working Paper 1814, (Washington D.C.: World Bank, 2009), 56.

36 Standing Guy, Work after Globalization: Building Occupational Citizenship, (Cheltenham Edward Elgar 2010), 78.

${ }^{37}$ Sebagaimana diketahui blue-print profesi manusia telah bergeser ke arah pengembangan kapabilitas peserta didik. Bahkan, menurut laporan World Economic Forum, yang berjudul The Future of Jobs, dinyatakan bahwa masyarakat dunia sedang memasuki revolusi industri 4.0, tiap tahun sepertiga pekerjaan yang sekarang ada akan hilang dan sepertiga pekerjaan baru akan muncul. Keadaan ini makin menguatkan akan kebutuhan perubahan orientasi TVET dari
} 


\section{Penguatan Relasional akan Kearifan Lokal}

Secara politis, strategi mendekatan program studi dengan kearifan local, sejatunya, telah termaktub dalam perundangan system pendidikan nasional. Hanya saja kesadaran itu tidak menjadi tumpuan utama perumusan kebijakan pendidikan vokasi. Bahkan, pendidikan vokasi seakan latah seperti sekolah umum pada bidak tujuan berbeda. Padahal secara teoritik, James J Watter, dkk melakukan riset terkait efektifitas school industrial partnership sekaligus daya serap terhadap lulusan sekolah vokasi. Ia pun berkesimpulan bahwa hubungan sekolah dan sector pekerjaan yang akan digeluti peserta didik, apabila masih berada pada wilayah atau daerah mereka, lebih mudah dikoneksikan dibandingkan lokasi pasar kerjanya ada di daerah lainnya. Dia juga merekomendasikan agar program studi harus bermuatan local lebih besar dibandingkan pengetahuan umum yang dibutuhkan pada industry global. Baginya, memberikan pengetahuan tanpa kesadara experiental tidak memiliki kegunaan apa-apa. ${ }^{38}$ Sama halnya dengan J. J. Watter, Kirya Mateeke Moses, dkk, menyatakan bahwa ada dua sisi yang bisa digabungkan ketika sekolah mempu mengkoneksikan antara sekolah dan dunia industry; pertama, pemahaman yang lebih lengkap perangkat tekhnis yang dibuat oleh daerah. Kedua, bisa mengajak pakar di bidang industry untuk memberikan pengetahuan dan pengalaman secara langsung kepada siswa di lingkungan pendidikan. ${ }^{39}$

\section{Pembahruan sistem Informasi dan Teknologi}

Sedikit berbeda dengan bentuk-bentuk inovasi yang dilakukan di atas, pembaharuan system teknologi dan informasi lebih condong untuk dibaca sebagai pemanfaatan oleh lembaga saja. Artinya, strategi ini tidak spesifik membincangkan bagaimana potensi, kompetensi, kapabilitas, dan aspek-aspek subtantif lain yang mejadi kekhasan pendidikan vokasi di Indonesia. Dari sekian banyak hasil riset pemanfaatan teknologi di lingkungan pendidikan vokasi, penulis menemukan misalnya karya Hendra Jaya yang menyebut bahwa inovasi teknologi bisa dibuat melalui sisi laboratorium virtual bagi siswa di SMK. Laboratorium virtual ini digagas sebagai pemikiran inovatif, karena kecenderungan di era digital yang sangat berpengaruh. Laboratorium virtual akan lebih memberikan pengalaman awal, sebelum mereka masuk ke dunia praktek

pengembangan kompetensi ke kapabilitas, untuk menyiapkan generasi yang memiliki kelenturan dengan jenis kemampuan masa depan dalam area okupasi yang telah dipilihnya. Lihat Moenjak, T. and Worswick, C., "Vocational Education in Thailand: A Study of Choice and Returns," Economics of Education Review, Tahun 2003: 99 - 107.

${ }^{38}$ James J Watter, et al, "School industry Partnerships; an innovative strategy for vocational Education" Vocational Education and Traning Conference in Turkey, 2013, 1-14.

${ }^{39}$ Kirya Mateeke Moses, Muladi, and Aji Prasetya Wijaya, "The Linkage between Vocational School and Industries Cooperation," International Conference on Education in UM Malang, 2016, 483. 
secara langsung. ${ }^{40}$ Lain dengan Hendra Jaya, Lyna Ukti Ulansari, dkk, menyatakan bahwa penggunaan produk teknologi bisa dipakai para guru untuk mengkongkretkan pengetahuan yang kognitif ke arah yang lebih nyata, sehingga kualitas utama pendidikan vokasi bisa dicapai. ${ }^{41}$ Pada intinya, inovasi di bidang ini, tidak bisa langsung memberikan dampak baru terhadap model-model pendidikan vokasi di Indonesia. Terkecuali, memerankan produk teknologi sebagai pendekatan baru pembelajaran dan peningkatan pengetahuan peserta didik.

Sedikitnya, itulah pandangan-pandangan terkait problem yang dihadapi pendidikan vokasi di Indonesia. Sekaligus, bagaimana jalan keluar yang ditawarkan secara teoretik dan praktis oleh para peneliti yang concern akan pendidikan vokasi. Tentu, penulis menyadari bahwa ekspolari pendekatan di atas, masih membutuhkan preferensi lain terkait keterbatasan pada studi-studi yang dilakukan oleh pakar tersebut. Misalnya saja, pada sisi pengembangan jiwa entreneurship di SMK. Sebagaimana dikenal, konsep pendidikan kewirausahaan di Indonesia masihlah abstrak dan berbentuk informasi tentang dunia usaha saja. Belum ada langkah kongkrit bagaimana pendidikan kewirausahaan bisa menjadi basis structural dan cultural, bahkan menjadi desain pendidikan yang efektif di Indonesia, termasuk di dalam jurusan ilmu ekonomi, bisnis, dan manajemen itu sendiri. Ada banyak lulusan program tersebut bimbang mengaktualisasikan kemampuan akademik yang mereka dapatkan melalui dunia pendidikan yang digelutinya.

\section{Model-model Pendidikan Vokasi SMK berbasis Pesantren di Banyuwangi}

Seperti yang telah penulis paparkan sejak awal terkait bagaimana konstruk teoritik dan faktual pendidikan vokasi di Indonesia, sekaligus berbagai macam inovasi yang dijalankan untuk meningkatkan kualitas pendidikan tersebut. Maka, pada bagian ini penulis akan memberikan gambaran bagaimana modelmodel pendidikan vokasi di lingkungan pondok pesantren, berdasarkan pada tiga SMK di Banyuwangi; SMK Bustanul Falah, SMK Darussalam, dan SMK Mambaul Ulum Muncar. Sekali lagi, penulis ingin menyebutkan bahwa ketiga SMK di lingkungan pesantren ini ditunjuk oleh Dinas Pendidikan Kab. Banyuwangi sebagai SMK model (baca; percontohan) bagi lembaga-lembaga lain, khususnya bagi sekolah SMK swasta yang ada sekitar 78an SMK di Kab. Banyuwangi. Selain itu pula, secara normative, ketiga SMK telah mendapatkan akreditasi (A), terkecuali SMK Mambaul Ulum mendapatkan nilai (B). Terkait hal tersebut. Bapak

\footnotetext{
${ }^{40}$ Hendra Jaya, "Pengembangan Laboratorium Virtual untuk Kegiatan Praktikum dan Menfasilitasi Pendidikan Karakter di SMK," Jurnal Pendidikan Vokasi, Vol 2 No 1, 2012 (UN Yogyakarta), 83.

${ }^{41}$ Lyna Ukti Ulansari dkk., "Inovasi Sekolah berbasis Teknologi Informasi dalam Meningkatkan Mutu Pendidikan Kejuruan," Jurnal Administrasi Publik Vol 3 No 11 tt, 1851-1856.
} 
Ahmadi, kepala sekolah SMK Mambaul Ulum memberikan penjelasan kepada penulis:

"Kita memang sengaja pak. Kami meminta Tim Assesor Akreditasi memberikan nilai bagus ( $B$, penulis). Karena asumsinya begini, kalau telah $A$, maka pemerintah akan lepas tangan. Tidak akan memberikan bantuan, sedangkan kita masih butuh banyak bantuan pemerintah. Yang terpenting bagi kami adalah kepercayaan masyarakat pada kita, bukan nilai administrasi yang seperti itu."

Terlepas dari persoalan itu, semua kepala SMK ini seraya bersepakat bahwa pondok pesantren merupakan added values yang dimiliki untuk pengembangan lembaganya. Bapak Natsir, Kepala Sekolah Bustanul Falah, memberikan penjelasan:

"...mungkin, kalau tidak di lingkungan pesantren, SMK ini tidak akan secepat ini perkembangannya. Saya kira akan bernasib sama dengan SMK lain di Banyuwangi yang memiliki banyak problem pengelolaan. Salah satu keuntungannya adalah komunikasi kita dengan masyarakat dan pemerintah sangat terbantu oleh keberadaan kiai dan yayasan. Kita sadar punya keterbatasan ruang kelas hari ini dan ruang praktek. Namun karena kita di pesantren, maka proses belajar mengajar itu tidak tabu kalu diletakkan di Mushola. Di ruangan pengajian malam para santri. Siang kita letakkan di lembaga PAUD dan lain-lain. Tapi ini khusus mata pelajaran yang komponennya pengetahuan (pure kompetensi akademik, pen). Kalau praktek tetap harus di ruang praktek. Satu lagi, kita juga bisa memasukkan pendidikan diniyah sebagai nilai tambah. Ini bisa menyudahi problem kewajiban anak mendapatkan pendidikan karakter yang benar, sesuai dengan aturan pemerintah". 43

Demikian halnya dengan pandangan Kepala Sekolah SMK Darussalam Bolokagung. Baginya, keberadaan pesantren bisa dijadikan sebagai pengikat kedisiplinan siswa. Norma-norma agama yang menjadi ciri khas keteguhan sikap masyarakat tradisional, dianggap menjadi sarana paling efektif untuk mengurangi sikap-sikap 'melenceng' daripada kecenderungan siswa SMK atau Teknik pada umumnya; di mana mereka cenderung acuh tidak acuh pada guru mata pelajaran yang tidak berhubungan dengan praktek kerja mereka, control emosi yang labil karena tidak banyak berinteraksi satu sama lain, dan aspek-aspek lainnya. ${ }^{44}$ Bahkan, hal yang sangat mengejutkan dan berkesan pada penulis adalah keberanian SMK Mambaul Ulum Muncar untuk mewajibkan semua siswi untuk

42Wawancara Pribadi pada 30 Agustus 2018. Secara observasional, penulis ingin menambahkan bahwa secara fasilitas dan aspek-aspek instrumentatif lainnya sekolah ini memang layak memiliki nilai A. Bahkan, kalau dibandingkan dengan dua lembaga objek penelitian ini, kelengkapan aspek-aspek instrumentatif, penulis bisa katakana sepadan. Mungkin pula lebih baik. Misalnya saja berhubungan dengan iklim dan suasana pembelajaran yang telah memiliki Air Conditioner (AC), ruang praktek lengkap, dan guru-guru professional yang dibuat menggunakan exchange experiences dengan SMKN Darul Ulum (di samping SMK Mambaul Ulum).

${ }^{43}$ Wawancara Pribadi Pada 28 Agustus 2018

${ }^{44}$ Wawancara Pribadi Pada 23 Agustus 2018 
menggunakan jilbab, termasuk bagi siswi non-Muslim. Menurut pandangan Kepala Sekolah, jilbab ini adalah bentuk kebijakan dari seragam sekolah, bukan persoalan agama. Artinya, siapapun yang mau melanjutkan pendidikan di SMK Mambaul Ulum perempuan wajib menggunakan seragam sekolah (baca, wajib berjilbab). Ia pun menambahkan bahwa kebijakan ini tidak banyak ditentang masyarakat, sebab mereka memahami bahwa ini kebijakan sekolah, bukan kebijakan yang diambil atas nama agama. Tercatat pula, ada tiga latar agama yang ada di SMK Mambaul Ulum; Kristen, Hindu dan Budha. 45

Tidak sekedar keleluasaan - di mana pesantren sebagai pendukung dan alat komunikasi - membangun inovasi di bidang kebijakan-kebijakan sekolah dan pendisiplinan siswa. Kiai sebagai pemimpin tertinggi di pesantren juga memberikan dampak yang sangat positif untuk membangun inovasi kelembagaan. Kepala Sekolah SMK Darussalam Bolokagung menyebutkan bahwa ada empat keunggulan SMK berada di bawah pesantren; pertama, keunggulan melakukan komunikasi terhadap masyarakat dan pemerintah. Kedua, kiai bisa memberikan pandangan terkait standar guru yang akan direkrut; misalnya, mereka harus memiliki latar kepesantrenan dan organisasi Nahdlatul Ulama', terkecuali pada posisi tertentu di mana SDM pesantren dan NU tidak bisa menempati posisi tersebut. Ketiga, beragamnya jejaring para kiai dalam kehidupan social; mulai dari pengusaha, politik, dan pengelola lembaga pendidikan. Ketiga, modal social sebagai kepercayaan masyarakat dalam kehidupan sehari-hari. ${ }^{46}$ Hal lain ditambahkan oleh M. Natsir, ialah kiai selalu memberikan kepercayaan penuh terhadap guru dan kepala sekolah untuk memberikan pelayanan terbaik bagi semua siswa yang ada. Kiai jarang mengintervensi kebijakan sekolah, terkecuali kebijakan tersebut dianggap melanggar aturan agama dan tradisi pesantren. ${ }^{47}$ Bapak Ahmadi memberikan contoh kongkrit ketika para siswa diminta Pemerintah Kabupaten untuk menjadi penerima tamu kenegaraan. Kepala sekolah Mambaul Ulum ini hanya mengirimkan para siswa (baca; non-Siswi) karena menganggap hal tersebut akan dilarang oleh kiai. ${ }^{48}$

Paparan data di atas, semuanya berhubungan dengan sumber-sumber keleluasaan inovasi yang ada di SMK Pesantren, sekaligus keunggulannya. Pada frasa selanjutnya, penulis ingin memaparkan bagaimana pengelolaan inovasi yang telah dibuat secara kebijakan, serta bagaimana respon para guru dan kepala

\footnotetext{
45 Wawancara Pribadi pada 30 Agustus 2018

46 Wawancara Pribadi Pada 23 Agustus 2018

${ }^{47}$ Salah satu contohnya adalah ketika para siswa-siswi diwajibkan mengikuti karnaval kesenian daerah. Kepala sekolah harus berinovasi memamerkan busana yang tidak melanggar aturan agama. Siswi khususnya harus tetap bisa menutup aurat mereka sesuai ajaran agama. Wawancara Pribadi Pada 28 Agustus 2018.

48 Wawancara Pribadi Pada 30 Agustus 2018
} 
sekolah terhadap perubahan-perubahan paradigmatic pengelolaan pendidikan vokasi di Indonesia. Pada taraf pengembangan entrepreneurship based curriculum. Ketua Penjamin Mutu SMK Bustanul Falah menyatakan bahwa:

“...Pesantren itu memiliki sumber nilai kemandirian hidup. Kedekatan dengan masyarakat dan memiliki akses yang tidak terbatas untuk membangun kerjasama. Lebih-lebih disini pak. Jadi, kalau kita ditanya respon terkait kewirausahaan. Kita punya kurikulum kewirausahaan itu di kelas XII. Di kelas XII, para siswa itu kita pilah menjadi dua kelompok. Siswa yang ingin melanjutkan ke perguruan tinggi. Dan siswa yang ingin bekerja. Yang pengen bekerja ini kita bedakan jadi dua lagi. Mereka yang mau ke pasar kerja dan mereka yang ingin membangun usaha. Yang mau bekerja di perindustrian dan pariwisata, seperti yang ada di sini, kita akan fasilitasi mereka untuk berhubungan dengan para alumni yang ada di perusahaan tersebut. Kita tidak membebaskan mereka memilih sendiri. Karena apa, setau saya, di dunia kerja itu butuh preferensi. Preferensi di dunia usaha, biasanya, dari karyawannya. Makanya, saya meminta mereka memilih di mana ada alumni SMK sini. Biar lebih memudahkan saja...Tapi, kalau dia punya akses lain dan yakin kita fasilitasi pengalaman dan pengetahuan saja...Bagi siswa yang mau berwirausaha, kita akan membantu dia sampai pada pameran karya dan pemasarannya. Nah, khusus siswa yang berwirausaha, mereka tidak diperbolehkan meninggalkan sekolah sampai mereka berhasil membuat produk plus pemasarannya. Kiai dan kami para guru membimbingnya secara langsung..."49

Lebih awal dibandingkan SMK Bustanul Falah, dua SMK lain memberikan pembekalan terkait kurikulum kewirausahaan sejak kelas XI. Meski mereka menyadari bahwa kurikulum yang diajarkan masih sekedar informasi bagaimana pentingnya berwirausaha dan peluang apa saja yang bisa diakses setelah lulus. Selain itu juga, kecenderungan beberapa siswa di sekolah mereka juga lebih menginginkan untuk melanjutkan ke pendidikan yang lebih tinggi. Alasan yang paling sering diungkapkan adalah agar mereka tidak sekedar bisa menjadi tekhnisi semata, melainkan bisa meningkat dari karyawan menjadi siswa yang critical-high skill. Paparan Wakil Ketua Kurikulum SMK Mambaul Ulum menyebut bahwa kepentingan entrepreneurship terkadang juga berhubungan dengan modal usaha. Bukan sekedar nilai-nilai kreatifitas para siswa. Jadi, sekolah tidak mendahulukan hal tersebut, sebab serapan dunia usaha terhadap lulusan SMK di Banyuwangi masih tergolong sangat banyak. Yang memang perlu dilakukan adalah menambah varian-varian pengetahuan yang diajarkan kepada siswa, bukan mendahulukan siswa untuk menjalankan usaha-usahanya sendiri.50

Sedang yang berkaitan dengan perubahan paradigma dari kompetensi teknik ke kapabilatas siswa, tiga SMK ini memilih pendekatan yang sama, yakni; "Praktek dulu, baru materi dituntaskan". Di SMK Mambaul Ulum Muncar, materi ajar berbasis kelas diberikan setelah praktek keahlian dilaksanakan oleh siswa.

49 Wawancara Pribadi dengan Ketua Lembaga Penjamin Mutu SMK Bustanul Falah Pada 28 Agustus 2018.

50 Wawancara Pribadi dengan Waka Kurikulum SMK Mambaul Ulum Pada 30 Agustus 2018. 
Pasalnya, menurut dia, pilihan rasional seorang siswa atau orang tua memasukkan anaknya ke SMK adalah untuk memiliki keterampilan tekhnis. Tidak sekedar memahami materi. Jadi concern mereka ada praktek. Ia pun menambahkan, kalau praktek diletakkan setelah materi, maka kreatifitas siswa menyelesaikan problem yang dihadapi sangat tekstualis dan normative. Sama dengan asumsi tersebut, SMK Darussalam Bolokagong menerapkan in-learning service agar upgrading terhadap pengetahuan mereka bisa didapat setelah memiliki pengalaman. Dalam bahasa etnografis mereka adalah "mengkaitkan pengalaman dengan pemahaman teori". Artinya, para siswa akan merangkai pengalaman berhadapan dengan problem lebih awal, lalu mereka mengukurnya dengan teori-teori yang beragam di dalam kelas. Di SMK Bustanul Falah memberi nama perluasan ini dengan istilah "belajar tuntas, berbasis produk". Jadi, para siswa yang sedang praktek, tidak dibatasi jam dan waktu. Mereka bisa melakukan interaksi kapan saja menggunakan model komunikasi teknologi yang berkembang saat ini. Pada prosesnya pula, mereka dibiarkan untuk mencari cara secara leluasa melalui internet atau sumber lainnya, menyelesaikan produk tersebut, tanpa bimbingan materi di dalam kelas.

Yang terakhir adalah penyelarasan program studi dan pengembangan pembelajaran berbasis teknologi. Dalam hal ini, dari tiga lembaga yang ada, terlihat jelas perlakuan yang berbeda. Bagi mereka, persaingan-persaingan dunia kerja hari ini memang belaum sampai pada aspek penggunaan proses digitalisasi di era revolusi industri 4.0. Persaingan - khususnya di local Kab. Banyuwangi masih tergolong bercorak pada sisi-sisi pengetahuan tekhnis belaka. Hal yang mungkin sedikit menarik untuk ditampilkan pada konteks pembacaan tantangan masa depan ialah pandangan Kepala Sekolah SMK Bustanul Falah. Ia menyatakan bahwa:

“...selama ini, kepala-kepala sekolah SMK di Kab. Banyuwangi itu berkumpul dan menjadi satu grup komunikasi. Kita punya grup WhatssAp yang isinya adalah para pengelola SMK se Kab. Banyuwangi. Dari situ, kita berinovasi, karena apa..., kita sering disugukan wacana-wacana baru ke depan. Termasuk kebijakan-kebijakan penggunaan atau pemanfatan lulusan oleh Dunia Usaha (DUDI,pen), atau lembagalembaga vokasi di atas sekolah SMK, semisal perguruan tinggi ataupun lembagalembaga profesi kerja lainnya. Kita juga berkolaborasi dengan instansi pemerintah yang menyalurkan beberapa gagasan pengembangan daerah ke depan. Jadi, semuanya kita bisa lihat dan terkomunikasikan dengan cukup baik. Persoalan lonjakan lulusan SMK di Banyuwangi sendiri tidak juga menjadi problem utama. Sebab, ya seperti yang saya katakana di awal, tidak semua siswa SMK orientasinya adalah menjadi pekerja. Mereka juga ingin melanjutkan ke jenjang yang lebih tinggi dan sebagian lainnya menjadi penggerak usaha di daerah mereka masing-masing. Jadi, sumber berinovasi selain karena kita melihat realitas yang ada di sekolah, juga diberi informasi oleh stakeholder, user, dan masyarakat luas yang ada di Kab. Banyuwangi. Selain itu, per hari ini, Kab. Banyuwangi juga masih sangat membutuhkan banyak lulusan SMK di semua bidang, karena program Peningkatan 
ekonomi pemerintah juga tersinkron dengan program sekolah yang akan dijalankan. ${ }^{\prime 51}$

Berdasarkan beberapa paparan data di atas, pendidikan vokasi di pesantren memiliki dua ciri khaspenting; pertama, adanya kekuatan karakter yang diambil dari tanaman nilai-nilai kepesantrenan, sehingga para siswa selain memiliki kompetensi, kapabilitas, dan keterampilan, mereka juga punya tanaman nilai-nilai keagamaan yang juga kuat. Hanya saja, harus pula diakui keunggulan seperti ini bisa dibaca secara terpilah. Artinya, keberadaan pesantren akan menjadi kontra produktif apabila pesantren menggunakan pendekatan institutionalisomorphism (pengetatan/pemaksaan institusional), khususnya terkait pelaksanaan nilai-nilai keagamaan dan kepesantrenan. Kontra produktif karena pemaksaan itu bisa merubah orientasi siswa yang harusnya fokus untuk memahami dan meningkatkan keterampilan mereka, menjadi siswa 'umum' yang mengenyam pendidikan untuk bekal hidup beragama atau bermasyarakat saja (baca; kembali pada ruang kognitif). Kedua, keluesan akses yang dimiliki kiai (pimpinan pesantren). Sebagaimana kita ketahui, akses kiai untuk mengembangkan lembaganya penulis anggap seperti post-cultural and political leadership (melampui nalar normative berfikir seorang kepala sekolah). Apa yang diungkapkan oleh Kepala Sekolah Mambaul Ulum adalah bukti kongkrit bahwa keinginan kiai dan kepala sekolah melampaui corak berfikir normative mengelola lembaga pendidikan. Kendati, di SMK Bustanul Falah dan SMK Darussalam, akses yang dimiliki kiai tetap dikapitalisasi, meskipun akreditasi mereka telah sangat bagus.

Pilahan lain yang bisa diambil pelajaran dari proses mode inovasi pendidikan vokasi berbasis pesantren ialah pengayaan akan iklim pendidikan dan proses pembelajaran yang akan dijadikan sebagai standard utama kualitas pendidikan tersebut. Penulis ingin memberikan contoh bagaimana pada sisi kurikulum pendidikan vokasi dirombak melalui cara berfikir yang sangat sederhana. Dari tiga lembaga ini, penulis mengklaim, bahwa tidak satupun dari mereka mengikuti aturan normative yang ada di dalam desain pengembangan kurikulum pendidikan vokasi. Kurikulum berbasis in learning service di Bolokagung adalah jawaban untuk membuat kapabilitas para siswa memahami pengetahuan secara interaktif dan adaptif terhadap perkembangan zaman. Kurikulum tidak dibiarkan statis sebagaimana yang disebutkan oleh teks, sebab sarana yang dijadikan praktek juga telah berkembang sesuai dengan perkembangan teknologi yang ada. Demikian halnya dengan kurikulum praktek lebih awal dibandingkan pengetahuan. Frasa kurikulum ini sangat membutuhkan Tim Teaching yang solid. Sebab, satu praktek bisa saja mencakup banyak disiplin

51Wawancara Pribadi Pada 28 Agustus 2018 
pengetahuan yang dipertimbangkan untuk mengutamakan kapabilitas siswa menyelesaikan masalah-masalah yang dihadapinya.

Pada bagian ini, SMK Mambaul Ulum Muncar - yang lembaganya juga bersanding dengan SMK Negeri Darul Ulum - mampu membangun Tim Teaching dengan sangat baik untuk memberi tahu bagaimana proses tematik dan mempraktekkannya ke sarana yang dipakai. Terakhir adalah kurikulum berbasis produk. SMK Bustanul Falah melakukannya menggunakan pendampingan sesuai dengan keinginan para siswa yang secara kreatif bisa membuat sebuah produk yang bisa diterapkan dan memiliki nilai keekonomian dalam kehidupan seharihari. Kata kunci sukses pelaksanaan kurikulum ini adalah kreatifitas dan kolektifitas guru yang akan mendampingi para siswa menciptakan produk yang diinginkan. Kepala Sekolah SMK Bustanul Falah membuat Tim Asistensi guru laiknya Professional Learning Communities - agar semua keinginan para siswa terhadap produk tersebut bisa terdistribusikan sesuai dengan latar keilmuan yang dimiliki guru-guru tersebut. Misalnya, ketika mereka harus membuat produk batik lukis melalui computer, maka guru bidang lukis dan desain grafis bertemu untuk membimbing bagaimana siswa yang memiliki ide difasilitasi sampai tuntas menjadi produk. Sedangkan tugas Kepala Hubungan Masyarakat adalah mendistribusikan produk ke masyarakat, melalui analisis segregasi dan segmentasi pasar yang juga jelas.

Masih dalam tahapan analisa nilai lebih yang dimiliki oleh SMK di pesantren. Penulis pun beranggapan bahwa pengimplementasian dan sustainsibilitas inovasi di berbagai bidang; mulai dari pembelajaran, kurikulum, dan penentuan kualitas lulusan, menjadi lebih mudah oleh factor trust (kepercayaan) masyarakat terhadap pesantren, khususnya di Jawa Timur. Demikian pula, kepercayaan politik yang diberikan pemerintah local kepada lulusan atau SMK berbasis pesantren. Faktor inipula, kalau dilihat secara observasional, pendidikan vokasi di pesantren bisa melampaui ekspektasi yang diinginkan oleh masyarakat. Di Jawa Timur saja, program santri-preneur, kelembagaan Bantuan Keuangan bagi pesantren dan SMK Pesantren lebih leluasa dibandingkan SMKN Negeri yang terikat secara normative melalui aturan keuangan negara, program keberpihakan Menteri Tenaga Kerja melalui Balai Latihan Kerja (BLK) yang juga akan diletakkan di lingkungan pesantren, serta bantuan-bantuan lain pemerintah, hingga pada akhirnya, memberikan akses pesantren dan SMK yang berada di bawah naungan otoritasnya bisa berkembangan sesuai dengan keinginan masyarakat sekitarnya.

Jadi, mode-mode inovasi apapun - asal masih bisa dinalar secara rasional dan dicarikan Sumber Daya Manusianya oleh Pesantren - maka pendidikan vokasi di pesantren akan berinovasi sesuai dengan harapan dan tuntutan zaman yang 
ada. Konsep entrepreneurship yang ditawarkan, sejatinya, merupakan bagian yang tidak terbisahkan dari kultur yang ada di pesantren, yakni; kesederhanaan dan kemandirian. Konsep perluasan dari kompetensi dan kapabilitas yang ditawarkan melalui TVETconcept sebagai nalar berfikir kurikulum, juga bisa dilaksanakan karena pesantren bisa memperluasnya menggunakan pendekatanpendekatan politis ataupun sosiologis. Faktor lokalisasi profesi pun demikian. Dunia Usaha dan pemerintah yang terkoneksi secara ekonomi dan politis pun akan sulit menegasikan peran pesantren untuk membangun kepercayaan masyarakat sekitar, lebih-lebih di wilayah Jawa Timur. Dunia usaha menganggap kedisiplinan santri, kerja keras, keinginan kuat dan keajegan dalam bekerja, bisa dijadikan penilain terpisah dari karakter karyawan lulusan SMK pesantren.

Terakhir adalah teknologi dan informasi. Hingga hari ini, sesuai data yang penulis dapatkan, semua SMK pesantren ini memiliki -learning yang dikelola dengan baik oleh lembaga tersebut. Hanya saja, semua keunggulan tersebut bisa saja hilang, apabila ada pembatasan kreatifitas yang dilakukan oleh para kiai atau pengurus yayasan kepada kepala sekoah atau guru untuk menjalankan program yang dinilainya baik dan terbarukan, terlebih jika berubungan dengan pengembangan pendidikan vokasi/keterampilan bagi para siswa yang ada di lingkungan pesantren. Artinya, otentisitas kepemimpinan kiai yang dominan, sedikit demi sedikit harus dirombak menjadi lebih transformasional dan demokratik; lebih-lebih bagi kepala sekolah yang terkoneksi secara intelektual dan profesionalitas untuk membangun serta mengembangkan pendidikan vokasi yang ada di lingkungan pesantren. Untuk mempermudah pemahaman terhadap pembahasan hasil penelitian ini, penulis akan men-framing temuan penelitian ini sebagaimana bagan berikut;

\section{Bagan 1. Innovative Modes of Pesantren-Based Vocational School}
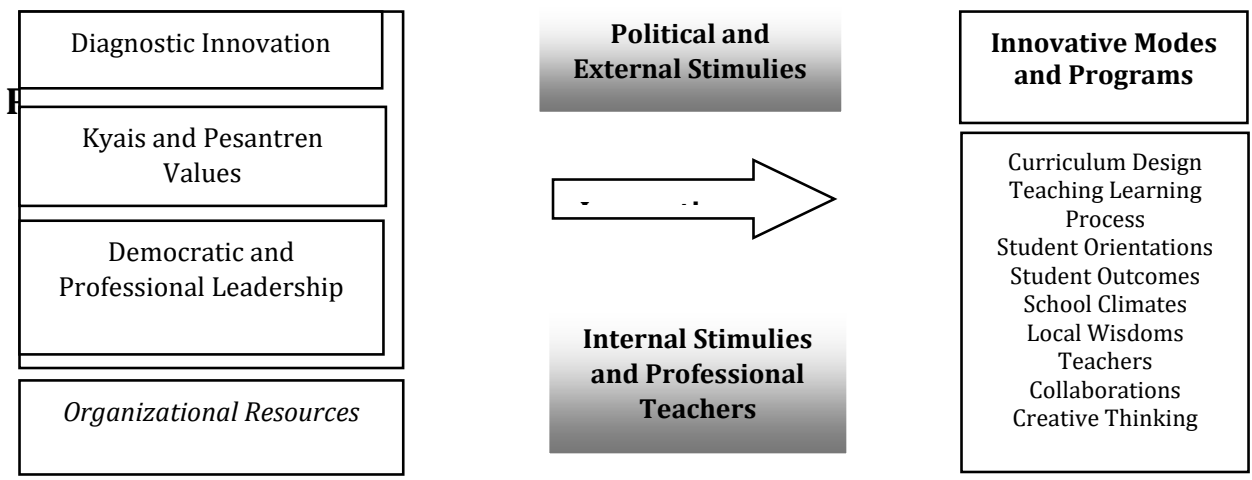

Berdasarkan pada bagan di atas, penulis ingin menggambarkan bahwa; pertama, diagnosis inovasi pendidikan vokasi di pesantren berakar dan bersumber dari keluasan akses kiai, nilai-nilai kepesantrenan yang bisa dijadikan 
holding culture dan modal komunikasi membangun kepercayaan masyarakat. Lalu dikuatkan dengan kepala sekolah yang paham serta berinteraksi dengan perkembangan pengetahuan pendidikan vokasi di Indonesia. Sekaligus didukung pula oleh guru-guru yang professional di lingkungan pendidikan tersebut. Kedua, kekhasan yang ada di pendidikan vokasi di pesantren adalah keberadaan kiai dan kepercayaan tinggi pemerintah; apakah itu karena keberpihakan politik kekuasaan semata atau murni profesionlisme untuk kepentingan masyarakat yang luas. Kendati telah ada keberpihakan kuat pemerintah, ada pula alasanalasan implementasi program tersebut dijalankan kareman factor internal atau desakan internal, semisal adanya kekurangan sarana untuk pendidikan atau kreatifitas guru yang tidak bisa dipasung untuk proses pembelajaran para siswa. Ketiga, orientasi pengembangan inovasi pendidikan vokasi pesantren ada pada beberapa sisi. Yang paling kuat adalah sisi kurikulum dan proses iklim pembelajaran yang lebih adaptif terhadap perkembangan zaman, sebab mereka memiliki otoritas pengembangan yang lebih leluasa daripada lembaga negeri.

\section{E. Penutup}

Pada kesimpulannya, secara teoritik, melalui penelitian ini penulis beranggapan ada beberapa hal yang bisa dipakai untuk melihat bagaimana inovasi bisa dijalankan. Menambahi apa yang dilakukan oleh J. Birkinshaw, Hamel, dan peneliti lainnya terkait inovasi, penulis menganggap kekuasaan (politik) bisa menjadikan diagnosis inovasi bisa berjalan lebih luas dibandingkan sekedar cultural (budaya yang dibangun melalui organisasi), struktural (badan khusus yang disediakan untuk mengkreasikan pandangan baru), atau pilihan rasional kepemimpinan. Pasalnya, sebagaimana dikatakan Ball, politik bisa menjadikan organisasi sekolah lebih terbuka terhadap stimulasi dari luar. Politik juga bisa menyeimbangkan antara pilihan rasional dan model komunikasi terhadap masayrakat yang berkepentingan akan kualitas atau mutu sebuah pendidikan. Politik, yang banyak dipraktekkan oleh kiai pesantren, bisa mengakomodasi keberpihakan pemerintah dan juga masyarakat sekaligus menjadi capital untuk membangun daerah ataupun kepentingan ideologi nasional. Selain itu, melalui penelitian ini juga, orientasi dan model-model inovasi bisa diletakkan pada beberapa sisi dengan pendekatan-pendekatan yang berbeda; jika hal itu berhubungan dengan kualitas proses pelaksanaan pendidikan vokasi, maka atribusi guru professional dan latar pengalaman pendidikan akan menjadikan inovasi berjalan dengan efektif. Sebaliknya, jika berhubungan dengan student outcomes dan public relation dengan dunia usaha, maka kembali pada frasa awal bahwa kepemipinan dan inter-relasi kuasa kiai dan pesantren akan menjadi penentu sebuah inovasi di pendidikan vokasi pesantren berjalan dengan efektif dan efisien. 


\section{F. Referensi}

Ahmad, Dzaujak. Penunjuk Peningkatan Mutu Pendidikan di Sekolah Dasar. Jakarta: Depdikbud, 1996.

Aisyah, Siti. "SMK Pesantren; Sebuah Penelusuran Akar Ideologi Pendidikan." Jurnal Manajemen Pendidikan Islam, 2017: 81-102.

Asmar Yulastri, Hendra Hidayat, dan Ganefri. "Learning Outcomes with the Application of Product Based Entrepreneurship Module in Vocational Higher Education." Jurnal Pendidikan Vokasi, 2018: 120-130.

Ball, Stephen J. Micro Politics of School; toward a Theory of School Organization. London: Springer, 2012.

Canady, Daniel L Duke \& Robert Lynn. School Policy. New Work: McGraw, 1991.

Charles Hoy, et.al. Improving Quality in Education. London: Longman Publishing Company, 2000.

Chen, D. Vocational Schooling, Labor Market Outcomes, and College Entry; Policy Research Working Paper 1814. Washington D.C.: World Bank, 2009.

Danim, Sudarwan. Visi Baru Manajemen Sekolah: dari Unit Birokasi ke Lembaga Akademik. Jakarta: Bumi Aksara, 2008.

Darmaningtiyas. Pendidikan yang Memiskinkan. Jogjakarta: Galang Press, 2004.

Depdiknas, Tim. Rencana Strategis Pendidikan Nasional; Konferensi Nasional Revitalisasi Pendidikan Nasional. Jakarta: Depdiknas, 2006.

dkk., Lyna Ukti Ulansari. "Inovasi Sekolah berbasis Teknologi Informasi dalam Meningkatkan Mutu Pendidikan Kejuruan." Jurnal Administrasi Publik 1851-1856.

Falah, Ketua Lembaga Penjamin Mutu SMK Bustanul, interview by Kholilur Rahman. (Agustus 28, 2018).

Fatah, Nanang. Sistem Penjaminan Mutu Pendidikan: dalam Konteks Penerpan MBS. Bandung: Remaja Rosdakarya, 2012.

Fitri. "“Kurikulum Nasional berbasis Kompetensi Harus mengacu pada KKNI"." Ristekdikti. April 28, 2013. http://lldikti12.ristekdikti.go.id/2013/04/28/kurikulum-nasionalberbasis-kompetensi-mengacu-pada-kkni.html. (accessed Agustus 23, 2018).

Guy, Standing. Work after Globalization: Building Occupational Citizenship. Cheltenham: Edward Elgar, 2010.

Hamel, Gary. "The Why, What, and How of Management Innovation." Harvard Business Review, 2006. 
Harususilo, Yohanes Enggar. kompas.com. September 17, 2018. https://edukasi.kompas.com/read/2018/09/17/21413501/lulusansmk-jadi-pengusaha-bisa (accessed September 23, 2018).

Hockley, Andy. "Managing Innovation in Educational Orgnanizations." Proceedings of the International Conference Creativity and Innovation to Promote Multilingualism and Intercultural Dialogue. Editura ARS LONGA, 2009. 177.

Isjoni. Pendidikan sebagai Investasi Masa Depan. Jakarta: Yayasan Obor Indonesia, 2006.

James J Watter, et.al. "School industry Partnerships; an Innovative Strategy for Vocational Education." Vocational Education and Traning Conference in Turkey. Turkey, 2013. 1-14.

Jaya, Hendra. "Pengembangan Laboratorium Virtual untuk Kegiatan Praktikum dan Menfasilitasi Pendidikan Karakter di SMK." Jurnal Pendidikan Vokasi, 2012: 83.

Julian Birkinshaw, et. al. Management Innovation. London: Springer, 2004.

Kemdikbud, Tim. Revitalisasi Pendidikan Vokasi. Jakarta: Kementerian Pendidikan dan Kebudayaan, 2016.

Khayati, Siti Qomala. "Manajemen dan Pengembangan Kurikulum Vokasi di Indonesia." Jurnal Mozaik; Islamic Education Journal, 2016: 23.

Kirya Mateeke Moses, Muladi, and Aji Prasetya Wijaya. "The Linkage between Vocational School and Industries Cooperation." International Conference on Education in UM Malang. Malang, 2016. 483.

Maksum, Ali. Sosiologi Pendidikan; buku perkuliahan S1. Surabaya: UINSA Press, 2013.

Malang, Universitas Muhammadiyah. Data SMA dan SMK Propinsi Jawa Timur. http://www.umm.ac.id/id/pages/jawa-timur-2.html (accessed Agustus 23, 2018).

Maskuri. Kebijakan Sekolah Menengah Kejuruan di Lingkungan Pondok Pesantren; Studi terhadap Peraturan Daerah Jawa Timur No 9 Tahun 2014 tentang Penyelenggaraan Pendidikan. Disertasi, Surabaya: UIN Sunan Ampel, 2018.

Mie Harder, et. al. Management Inovation Capabilities: A Typology and Propositions for Management Innovation Research. Denmark: Frederiksberg, 2000.

Moenjak, T. and Worswick, C. Vocational Education in Thailand: A Study of Choice and Returns. Economics of Education Review, 2003.

Moodie, L. Wheelahan and G. Rethinking Skills in Vocational Education and Training: From Competencies to Capabilities. NSW: Australian Education Union, 2011. 
Nasution, M.N. Manajemen Mutu Terpadu (Total Quality Management). Jakarta: Ghalia Indonesia, 2001.

Nuryadin Eko Raharjo, Sukardi, dan Husaeni Usman. "Entrepreneurial Character Education Through The School Culture in The Vocational High Schools." Jurnal Pendidikan Vokasi, 2018: 204-215.

Pinter, Cah. Daftar Alamat SMK se-Kab. Banyuwangi. Agustus 06, 2016. http://blog.unnes.ac.id/daftardaftar/daftar-alamat-smk-se-kabbanyuwangi/ (accessed Agustus 23, 2018).

Puterea, Uhar Suharsa. Kepemimpinan Inovasi Pendidikan; Membangun Spirit Entrepreneurship Menuju Learning School. Bandung: Refika Aditama, 2016.

Ramayulis. Pengantar Ilmu Pendidikan Islam. Bandung: Refika Aditama, 2000.

Rosyada, Dede. Paradigma Pendidikan Demokratis. Jakarta: Prenada Media, 2004.

Saetapi, Firman Ghana. Rumusan Sinergi Pemerintah Daerah dan Pusat. Slideshare Kementerian Dalam Negeri.

Sallis, Edward. Total Quality Management in Education. London: Kogan Page Limited, 2002.

Sugestiyadi, Bambang. Pendidikan Vokasional sebagai Investasi; strategic Option for managing Knowledge and Innovation. Jogjakarta: UNY Press, 2011.

Sutarmanto, Hadi. Kewirausahaan dan Inovasi. Jogjakarta: Fakultas Psikologi UGM, 2004.

Tilaar. Standardisasi Pendidikan Nasional. Bandung: Rinneka Tjipta, 2008.

Ulum, Waka Kurikulum SMK Mambaul, interview by Kholilur Rahman. (Agustus 30, 2018). 
Kholilur Rahman 